\title{
Reading Genesis and the Fourth Commandment
}

\author{
JANNE ViLKUna
}

\section{Every individual and every community has a continually changing perception of itself. One of the central tasks in society for memorial or cultural heritage organizations is to assist in the construction of that perception.}

The core concern of preparing a museum exhibition is to understand the essential, and accordingly to simplify the message of the exhibition. Given the task of filling a hundred-square-metre room with an exhibition on the evolution from its origins to the beginning of the industrial era, we might spend many sleepless nights. Our feeling of relief would be great if we were to suddenly remember that the scenario for it has already existed for thousands of years.

All primitive societies have had a narrative of their own birth, a story of who they are. Such stories still exist, for what else are our continually updating works of historiography and scientific theories ${ }^{1}$. A good example of change is given by the conception of the beginning of all things. Basing on the genealogical lists of the Old Testament, the Protestant Irish bishop James Ussher (1581-1656) calculated in his best-known work Annales veteris testamenti, a prima mundi origine deducti (Annals of the Old Testament, deduced from the first origins of the world) from 1650 that God began the Creation on Sunday, 23 October $4004 \mathrm{BC}$. Today's scholars maintain that the Big Bang that created our universe took place 13.7 billion years ago. What might be the prevailing wisdom in the year 2350 ?

The narrative of creation which is the foundation of Western civilization and which Ussher used, originated thousands of years ago, but it could be recorded in script only after ca. $1000 \mathrm{BC}$, for it was only then that the Semitic alphabet that permitted writing came into use; the Hebrew alphabet was derived from it approximately a century later. According to some Biblical scholars, the events in the Sinai Desert can be dated to ca. 1200 BC, but the Pentateuch, or the Five Books of Moses, did not begin to be compiled in written form until the fifth century BC.

Our shared story of origin is thus Genesis (Latin for "birth") - the first book of the Old Testament. The chronologically distant authors of that narrative perceived with unbelievable clarity everything that is essential to culture.

I DISCUSS IN THE FOLLOWING THE CENTRAL VERSES OF GENESIS, QUOTED FROM THE King James Version of the Bible

2:19

"And out of the ground the LORD God formed every beast of the field, and every fowl of 
72 the air; and brought them unto Adam to see what he would call them: and whatsoever Adam called every living creature, that was the name thereof."

The educating mission of museology is to help us understand the "relations of power" of culture and time by studying the origins and use of the cultural heritage. It investigates how the individual and the community perceive and grasp their chronological and chorological environment by appropriating evidence of the past and the present. This evidence either remains in the environment as monuments or finds its way into collections as objects. The essential point, however, is that culture neither accepts or needs everything, but instead selects and in doing so it shapes and forges reality into cultural reality.

All cultures operate under the conditions of their respective environments. The relationship with the environment is most clearly evident in they ways in which cultures have taken possession of things and phenomena important to them by naming them. ICOM's theme for 2004 was "Museums and the Intangible Heritage". The language of a community is intangible heritage and its words and utterances reveal a whole culture. A classic example is how the indigenous peoples of Northern Eurasia subtly named the various forms and variants of elements vital to their way of life, such as snow, salmon and reindeer. The authors of Genesis were already aware of this classification as essential to man.

Museums cannot operate with collections and without classification there can be no command of collections (or of science and scholarship). Referring to this verse of Genesis on naming, taxonomists have somewhat wryly demanded to be recognized as practising the world's oldest profession.
3:1

Now the serpent was subtler than any beast of the field, which the LORD God had made. And he said unto the woman, Yea, hath God said, Ye shall not eat of every tree of the garden.

\section{3:6}

And when the woman saw that the tree was good for food, and that it was pleasant to the eyes, and a tree to be desired to make one wise, she took of the fruit thereof, and did eat, and gave also unto her husband with her; and he did eat.

\section{$3: 7$}

And the eyes of them both were opened, and they knew that they were naked; and they sewed fig leaves together, and made themselves aprons.

\section{3:22}

And the LORD God said, Behold, the man is become as one of us, to know good and evil: and now, lest he put forth his hand, and take also of the tree of life, and eat, and live for ever."

\section{$3: 23$}

Therefore the LORD God sent him forth from the garden of Eden, to till the ground from whence he was taken.

Many essential aspects are set in Paradise. The basic prerequisite of becoming human is the evolution of the brain to the point where we began to remember analytically. This is symbolized by the tasting of the fruit of the tree of the knowledge of good and evil. At that point we understood ourselves to individuals and saw that we were naked, which is not a problem for animals. We also comprehended the abstract three-part division of time into the past, present and future ${ }^{2}$, whereby we were able to 


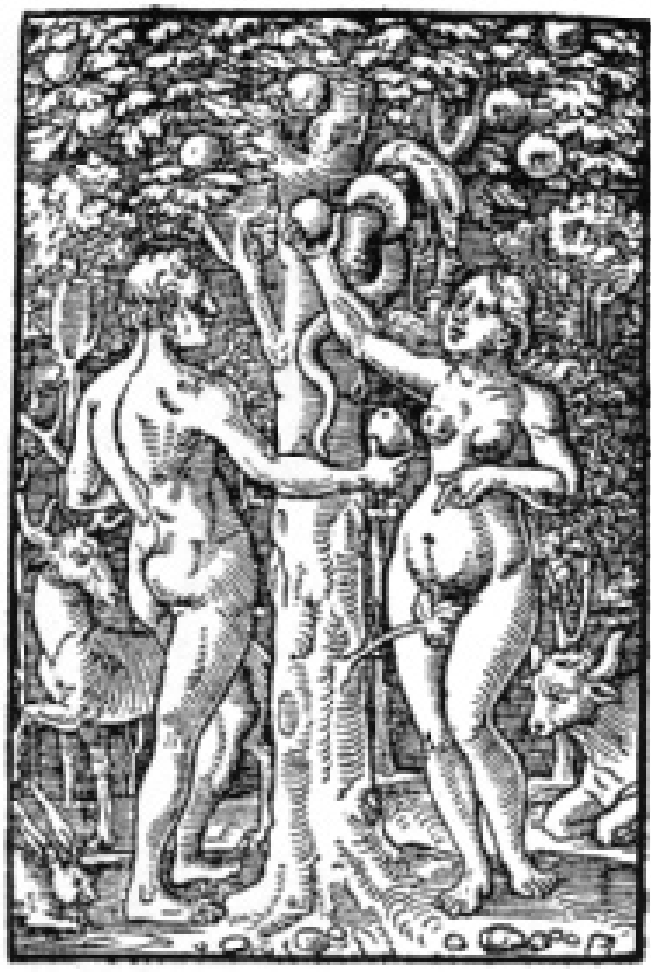

The Fall of Man according to Albrecht Dürer.

understand with the aid of our memory what was good or evil. It was thus that individual and communal memories, or heritage, came about. Along with heritage, physically limited man (Homo habilis) gained the appendages of a variety of cultural products, of which the aprons of Genesis to cover man's nudity were among the first.

Man has naturally been always intrigued by death and temporality, which according to Genesis had to be explained by another tree in Paradise, that of eternal life, and God did not want man to become like him by eating of it. Therefore, man was driven from Paradise and beset with eternal toil and tribulation (according to Bishop Ussher's calculations the expulsion took place on Monday, 10 November $4004 \mathrm{BC}$ ), and since then we have sought with all our strength and by using the means of culture to be free of the shackles of time and place and to be like the gods. All products of culture, both tangible and intangible, can be seen as the "appendages" of temporally and geographically limited man, with which we seek to become like the gods, beyond time and place. We come closest to them with the aid of our religions and our memorial or cultural heritage organizations.

\section{4:1}

And Adam knew Eve his wife; and she conceived, and bare Cain, and said, I have gotten a man from the LORD.

\section{4:2}

And she again bare his brother Abel. And Abel was a keeper of sheep, but Cain was a tiller of the ground.

\section{4:8}

And Cain talked with Abel his brother: and it came to pass, when they were in the field, that Cain rose up against Abel his brother, and slew him.

Paradise was also metaphorically the time when man was innocent, like the animals, and the time when man lived in nature gathering, hunting and fishing. The expulsion from Paradise was associated with the transition to the next stages of culture, described in terms of the descendants of the first man and woman. Abel symbolizes the nomadic cultures, and Cain the farming cultures. Gatherers, hunters, fishers and herdsmen have no use for an absurd abstraction such as (private) human ownership of land. It was invented by the farmer, who drew 
74 the first boundaries and set up the first fences. Thus began the eternal disputes over land. At the same time, man brought about war, described in Genesis as the slaying of the brother, and there have been wars since then.

The core values of our Western way of life are based on the Ten Commandments received by Moses from God as described in Exodus, the Second Book of Moses. Nine of the commandments clearly entail an explicit injunction "Thou shalt not" or an exhortation, but one of the commandments differs from the rest in that it contains a promise. The fourth commandment (Exodus 20:12) reads: "Honour thy father and thy mother", with the promise "that thy days may be long upon the land which the LORD thy God giveth thee."

The ultimate purpose of this commandment is not just to ensure respect for one's parents (and authority), for they are only instruments. The object of respect is namely the knowledge and skills that one's parents originally received from their parents, i.e. the cultural heritage. The goal of heeding this commandment is thus to ensure the inheritance and continuity of intangible capital important for each community.

Memorial or cultural heritage organizations and teaching and educational organizations came about when local communities evolved into civilizations. They replaced the heritage process that was taught and transmitted among closely related people in the community, and with their aid, we can remember further back, more and longer than any individual can.

\section{NOTES}

1. See e.g. Vilkuna, Janne. Time-bound theories about the origin of the Finns. Acta Borealia Volume 18, 1-2001.

2. Cf. the division of time presented by the Church Father Aurelius Augustine (354-430) in his

Confessions: the present of the past (remembrance), the present of the present (attention) and the present of the future (expectation)

Janne Vilkuna is professor in museology at the Jyväskylä University.

E-mail:jvilkuna@campus.jyu.fi 